\title{
The Influence of Cutting Roots on the Growth and Fruiting of 'Top Group' Plum Cultivars
}

\author{
Viorel MITRE ${ }^{1 *}$, Andreea ANDRECAN ${ }^{1}$, Sabin MOLNAR ${ }^{1}$, Maria CODREA ${ }^{1}$, Vasile MELNIC ${ }^{1}$, Lehel \\ LUKACS $^{2}$ and Berta Ştefania MOLNAR ${ }^{1}$ \\ ${ }^{1}$ University of Agricultural Sciences and Veterinary Medicine, Faculty of Horticulture, 3-5 Manastur \\ Street, Cluj-Napoca 400372, Romania \\ ${ }^{2}$ Horticultural Research Station Cluj-Napoca \\ *corresponding author, e-mail: viorel.mitre@usamvcluj.ro
}

BulletinUASVM Horticulture 76(2) / 2019

Print ISSN 1843-5254, Electronic ISSN 1843-5394

DOI:10.15835/buasvmcn-hort: 2019.0027

\begin{abstract}
The influence of cutting roots on the growth and fruiting of 'top group' plum cultivars ('Topfirst', 'Topfive', 'Toptaste', 'Tophit' and 'Topend Plus'), under the pedoclimatic conditions of Sînmihaiu Almasului, in the centre of Transylvania, Romania, in 2017-2018, was studied. The trees were grafted on Saint Julien rootstock, trained as Zahn Spindel and the orchard had a density of 1000 trees/ha. Roots were cut twice, at $40 \mathrm{~cm}$ distance from the trunk, in an angle of $45^{\circ}$ and $30 \mathrm{~cm}$ depth, as followed: first time in the autumn during the fall of leaves, on one side of the row and the second time in spring, at blooming time, on the other side of the row. The measurements were done each year after the leaves have been fallen. There were made observations on some growth parameters (length of shoots, height of trees, trunk sectional area, the fruits and vegetative branches ratio) and fructification (average yield for 2017-2018 period, and was determined the productivity index). The treatments influenced the shoot growth, height of the trees, cumulative yield, trunk cross sectional area, the ratio of the yield to a trunk sectional area, with differences statistically assured. Root pruning reduced the average length of shoots. The longest shoots, in mean values, gave the unpruned root variant $(131.0 \mathrm{~cm})$. Root pruning decreased the average length of annual growth $(51.1 \mathrm{~cm})$. The biggest average trunk cross sectional area with the unpruned root system was obtained $\left(58.7 \mathrm{~cm}^{2}\right)$. Also root pruning influenced the height of the trees. The best cumulative yield was obtained in the variant of root pruning system (28.75 t/ha) followed by the unpruned root system (25.87 t/ha). Finally, root pruning increased productivity. The biggest value was registered in 'Tophit' in the root pruned variant $(0.73 \mathrm{~kg} /$ $\mathrm{cm}^{2}$ ). The lowest value of productivity index was obtained in the unpruned system.
\end{abstract}

Keywords: fruiting, root pruning, top group, trunk cross-sectional area, vegetative growth, yield

\section{Introduction}

Maintaining an optimal balance between growth and fruiting is an ongoing concern of research in fruit growing (Cline et al., 2008). Besides the classical methods of reducing the vigor (cutting roots, low vigor cultivars, compact types, pruning in vegetation, balanced fertilization etc.) low vigor rootstocks is increasingly more used in order to reduce growth vigor and increase the number of fruit buds (Janssens et al., 2011; Pasa et al., 2011). Performance of a culture system of fruit trees are largely related to creating an optimal balance between growths and fruiting (Asín et al., 2007; Maas, 2008; Vercammen et al., 2005). Luxuriant vegetative growth delay the shade crown for entry bearing trees and reduce yield and fruit quality (Mitre et al., 2012; Hawerroth et al., 2012). In high-density cherry orchards, otherwise as in any fruit growing culture, the vegetative growth must be temperate and turned to bearing branches or to their support. In addition, the vegetative 
growth must be balanced with flowering (Hugard, 1980; Sharma et al., 2009; Walker, 1980).

The maintenance of proper equilibrium between the vegetative and reproductive processes is a major challenge in tree fruit production (Sharma et al., 2009).

There are many horticultural ways to maintain a permanent balance between growth and fruiting (Magda et al., 2015; Lang et al., 1987):

- dormant pruning (Forshey et al., 1992; Geisler and Ferree, 1984; Mika, 1986);

- summer pruning;

- root pruning (Geisler, Ferree 1984; Schupp, Ferree 1990);

- branch position (Elfving and Forshey,1976);

- use of plant growth regulators;

- deficit irrigation;

- fertilization;

- rootstocks (who control directly vegetative growth).

Unfortunately up to date none of these have proven to be universally successful (Sharma et al., 2009).

\section{Materials and methods}

The location of the experiment and orchard density

The research has been carried out in a plum orchard, during 2017-2018 at Sînmihaiu Almasului, in the centre of Transylvania, Romania. The orchard was established in 2012.

\section{Sampling design and cultivars}

The planting system chosen for the experimental plot was $5 \mathrm{~m}$ between rows and $2 \mathrm{~m}$ between trees within row, resulting a high density orchard with 1000 trees/ha. The trees were grafted on Saint Julien rootstock, trained as Zahn Spindel, and the orchard was assisted by fertigation system. The experience was a bifactorial one: first experimental factor was the root pruning system of the trees having two graduations (unpruned root and pruned root) and the second one the cultivar with five graduations ('Topfirst', 'Topfive', 'Toptaste', 'Tophit' and 'Topend Plus'). In order to correspond to such a bifactorial model, there were formed 30 experimental plots comprising 10 variants $(2 \times 5)$ in three replications. There were made observations on some growth parameters (length of shoots, trunk sectional area, height of trees) and fructification (cumulative yield for 2017-2018 period, productivity index).

\section{Cultural management of the plantation}

For the experiment plum trees were grafted on Saint Julien roottock. The technology of culture was a specific one to the plum high density orchard. The orchard was assisted by fertigation system. Roots were cut twice mechanically, at 40 $\mathrm{cm}$ distance from the trunk, in an angle of $45^{\circ}$ and $30 \mathrm{~cm}$ depth, as follows: first time in the autumn, during the fall of leaves, on one side of the row and the second time in spring, before blooming, on the other side of the row.

\section{Statistical procedures}

The results obtained were processed with the analysis variants of the bifactorial model of the divided plots, using analysis of variance, respectively Duncan's test to determine the significant differences between groups.

\section{Results and discussions}

Data of the Table 1 show an important influence on average length of annual growth in the experimental field with differences statistically assured. The longest shoots, in mean values, gave the unpruned root variant $(131.0 \mathrm{~cm})$. Root pruning decreased strongly the average length of annual shoots $(51.1 \mathrm{~cm})$. The cultivars behaved differently regarding the average length of shoots having differences statistically assured between them. The highest value of shoots average in 'Topend plus' was registered $(99.8 \mathrm{~cm})$ followed by 'Tophit' $(82.3 \mathrm{~cm})$, 'Toptaste' $(67.5 \mathrm{~cm})$, 'Topfive' $(53.8 \mathrm{~cm})$ and 'Topfirst' $(49.3 \mathrm{~cm})$, the first three varieties being the most vigorous.

Taking into account the combined action of two experimental factors, there can be observed that the longest shoots were obtained in "Topend Plus' in unpruned root variant $(131.0 \mathrm{~cm})$ and the shortest shoots at 'Topfirst' in root pruned variant $(37.0 \mathrm{~cm})$. Mitre et al. (2012) studied the effect of roots pruning upon the growth and fruiting of apple trees in high density orchards getting similar results, the longest shoots, in mean values, gave the unpruned root variant $(52.07 \mathrm{~cm})$, root pruning decreased strongly the average length of annual growth $(29.47 \mathrm{~cm})$. Also, Ferree (1992) noted that root pruning reduced terminal shoot growth of apple trees by about $20 \%$.

In pear trees, Asín et al. (2007) reported that root pruning significantly decreased shoot length by $25 \%$ compared with the non-root-pruned control. Steven et al. (2011) studied apple shoot 
Table 1. The influence of root pruning and the cultivar on average length of shoots $(\mathrm{cm})$ (Sînmihaiu Almasului, 2017 - 2018)

\begin{tabular}{lccc}
\hline \multirow{2}{*}{ Treatment } & \multicolumn{3}{c}{ Cultivar } \\
\cline { 2 - 4 } & Cut roots & Uncut roots & Mean of cultivar \\
\hline Topfirst & $37.0 \mathrm{~g}$ & $61.7 \mathrm{~d}$ & $49.3^{\circ}$ \\
\hline Topfive & $42.0 \mathrm{f}$ & $65.7 \mathrm{~d}$ & $53.8^{\circ}$ \\
\hline Toptaste & $52.0 \mathrm{e}$ & $83.0 \mathrm{c}$ & $67.5^{\mathrm{N}}$ \\
\hline Tophit & $56.0 \mathrm{de}$ & $108.7 \mathrm{~b}$ & $82.3^{\mathrm{M}}$ \\
\hline Topend Plus & $68.7 \mathrm{~d}$ & $131.0 \mathrm{a}$ & $99.8^{\mathrm{L}}$ \\
\hline Mean of treatment & $51.1^{\mathrm{B}}$ & $90.0^{\mathrm{A}}$ \\
\hline DS 5 \% Cultivar =6.7 -7.2 & & & \\
DS 5 \% Treatment $=4.2$ & &
\end{tabular}

Table 2. The influence of root pruning and the cultivar on height of the trees $(\mathrm{cm})$ (Sînmihaiu Almasului, 2017 - 2018)

\begin{tabular}{lccc}
\hline \multirow{2}{*}{ Treatment } & \multicolumn{3}{c}{ Cultivar } \\
\cline { 2 - 4 } & Cut roots & Uncut roots & Mean of cultivar \\
\hline Topfirst & $276.7^{\mathrm{c}}$ & $295.0 \mathrm{~b}$ & $285.8^{\mathrm{M}}$ \\
\hline Topfive & $273.3^{\mathrm{c}}$ & $296.7 \mathrm{~b}$ & $285.0^{\mathrm{M}}$ \\
\hline Toptaste & $312.0^{\mathrm{b}}$ & $359.3 \mathrm{a}$ & $335.7^{\mathrm{L}}$ \\
\hline Tophit & $318.0^{\mathrm{b}}$ & $357.0 \mathrm{a}$ & $337.5^{\mathrm{L}}$ \\
\hline Topend Plus & $315.0^{\mathrm{b}}$ & $347.7 \mathrm{a}$ & $331.3^{\mathrm{L}}$ \\
\hline Mean of treatment & $299.0^{\mathrm{B}}$ & $331.1^{\mathrm{A}}$ & \\
\hline DS 5 \% Cultivar = 13.9-15 & & & \\
DS 5 \% Treatment $=8.8$ & &
\end{tabular}

growth and yield responses to root pruning. Root pruning reduced the mean shoot length of 'Braeburn' compared with control, and was more effective at the dormant stage than at petal fall. The earlier treatment reduced final mean shoot length by about $60 \%$ compared with control.

Another important element that defines the vigor of growth is the height of the trees. Analyzing the data of the Table 2 one can observe that there are differences statistically assured between variants. Regardless the treatment, the highest value of the tree height in 'Topfive' cultivar was registered. Regardless the cultivar, the biggest value of tree height in unpruned root variant was obtained $(359.3 \mathrm{~cm})$ and the lowest in the root pruned one $(273.3 \mathrm{~cm})$. Concerning the combined influence of the two experimental factors the tallest trees in 'Toptaste' and unpruned root variant were registered $(359.3 \mathrm{~cm})$ and the smallest in 'Topfive' cultivar and pruned root system $(273.3 \mathrm{~cm})$.
A similar opinion was expressed by $\mathrm{Pal}$ et al. (2016), studying the root pruning effect on growth and yield of sweet cherry. The biggest value of trees height in unpruned root variant was obtained $(385.2 \mathrm{~cm})$ and the lowest in the root pruned one $(350.5 \mathrm{~cm})$.

Also, Khan et al. (1998) found that the height of apple trees was reduced by $12 \%$ in the second season and the shoot length, shoot number, and fruit diameter were all decreased as a consequence of root pruning.

Table 3 introduces data referring to the influence of the root pruning system of the plum trees and the cultivar on average trunk section area.

Analyzing the data of the Table 3, it can be observed that there are differences statistically assured between variants. Regardless the treatment, the highest value of the trunk section area in 'Topfive' cultivar was registered. 
Table 3. The influence of root pruning and the cultivar on average trunk sectional area $\left(\mathrm{cm}^{2}\right)$ (Sînmihaiu Almasului, 2017 - 2018)

\begin{tabular}{lccc}
\hline \multirow{2}{*}{ Treatment } & \multicolumn{3}{c}{ Cultivar } \\
\cline { 2 - 4 } & Cut roots & Uncut roots & Mean of cultivar \\
\hline Topfirst & $54.5^{\mathrm{ab}}$ & $58.2^{\mathrm{a}}$ & $56.4^{\mathrm{L}}$ \\
\hline Topfive & $38.8^{\mathrm{cd}}$ & $55.5^{\mathrm{b}}$ & $47.1^{\mathrm{N}}$ \\
\hline Toptaste & $43.9^{\mathrm{c}}$ & $50.9^{\mathrm{b}}$ & $47.4^{\mathrm{N}}$ \\
\hline Tophit & $48.1^{\mathrm{c}}$ & $62.8^{\mathrm{a}}$ & $55.5^{\mathrm{M}}$ \\
\hline Topend Plus & $56.3^{\mathrm{a}}$ & $66.3^{\mathrm{a}}$ & $61.3^{\mathrm{L}}$ \\
\hline Mean of treatment & $48.3^{\mathrm{M}}$ & $58.7^{\mathrm{L}}$ & \\
\hline DS 5 \% Cultivar = 5.35 - 5.78 & & \\
DS 5 \% Treatment $=3.38$ & & \\
DS 5 \% Interaction Cultivar $\times$ Rootstock $=7.56-8.71$ \\
\end{tabular}

Table 4. The influence of root pruning and the cultivar on the fruits and vegetative branches ratio of the plum tree (Sînmihaiu Almasului, 2017 - 2018)

\begin{tabular}{lccc}
\hline \multirow{2}{*}{ Treatment } & \multicolumn{3}{c}{ Cultivar } \\
\cline { 2 - 4 } & Cut roots & Uncut roots & Mean of cultivar \\
\hline Topfirst & 1.29 & 4.06 & $2.67 \mathrm{M}$ \\
\hline Topfive & 1.45 & 3.81 & $2.63 \mathrm{M}$ \\
\hline Toptaste & 2.14 & 3.35 & $2.75 \mathrm{~L}$ \\
\hline Tophit & 1.62 & 3.43 & $2.53 \mathrm{M}$ \\
\hline Topend Plus & 3.54 & 1.87 & $2.70 \mathrm{~L}$ \\
\hline Mean of treatment & $2.01 \mathrm{~B}$ & $3.31 \mathrm{~A}$ \\
\hline DS 5 \% Cultivar $=0.30-0.33$ & & & \\
DS 5 \% Treatment $=0.19$ & & & \\
DS 5 \% Interaction Cultivar $\times$ Rootstock $=0.43-0.49$ &
\end{tabular}

Regardless the cultivar, the biggest value of tree height in unpruned root variant was obtained $\left(66.3 \mathrm{~cm}^{2}\right)$ and the lowest in root pruned one (38.8 $\mathrm{cm}^{2}$ ). Concerning combined influence of the two experimental factors the highest value in 'Topend Plus' and unpruned root variant was registered $\left(66.3 \mathrm{~cm}^{2}\right)$ and the smallest in 'Topfive' cultivar and pruned root system $\left(38.8 \mathrm{~cm}^{2}\right)$.

Steven et al. (2011) studied the influence of crop density (fruit number/cm-trunk crosssection area) on mean fruit weight of 'Cox's Orange Pippin', where they found a negative linear relationship between mean fruit weight and crop density. The slopes of the lines for root-pruned and control trees was significantly different, whereas the constants were not significantly different.

In 15-years-old apple trees, this method of root pruning reduced trunk cross section area (TCSA) and shoot length without reducing fruit yield (Schupp et al., 1990).
Table 4 introduces data referring to the influence of the root pruning system of the plum trees and the cultivar on the fruits and vegetative branches ratio. Data of the Table 4 reveal that there are differences statistically assured between variants. Regardless the treatment, the highest value of the fruits and vegetative branches ratio in 'Topfirst' cultivar was registered. Regardless the cultivar, the biggest value of trees height in unpruned root variant was obtained (4.06) and the lowest in root pruned one (1.29). As combined influence of the two experimental factors is concerned, the highest value in 'Topfirst' and unpruned root variant was registered (4.06) and the smallest in 'Topfirst' cultivar and pruned root system (1.29).

Figure 1 presents data referring to the influence of the root pruning and the plum cultivar upon cumulative yield of 2017 and 2018 growing seasons. The best cumulative yield was obtained 


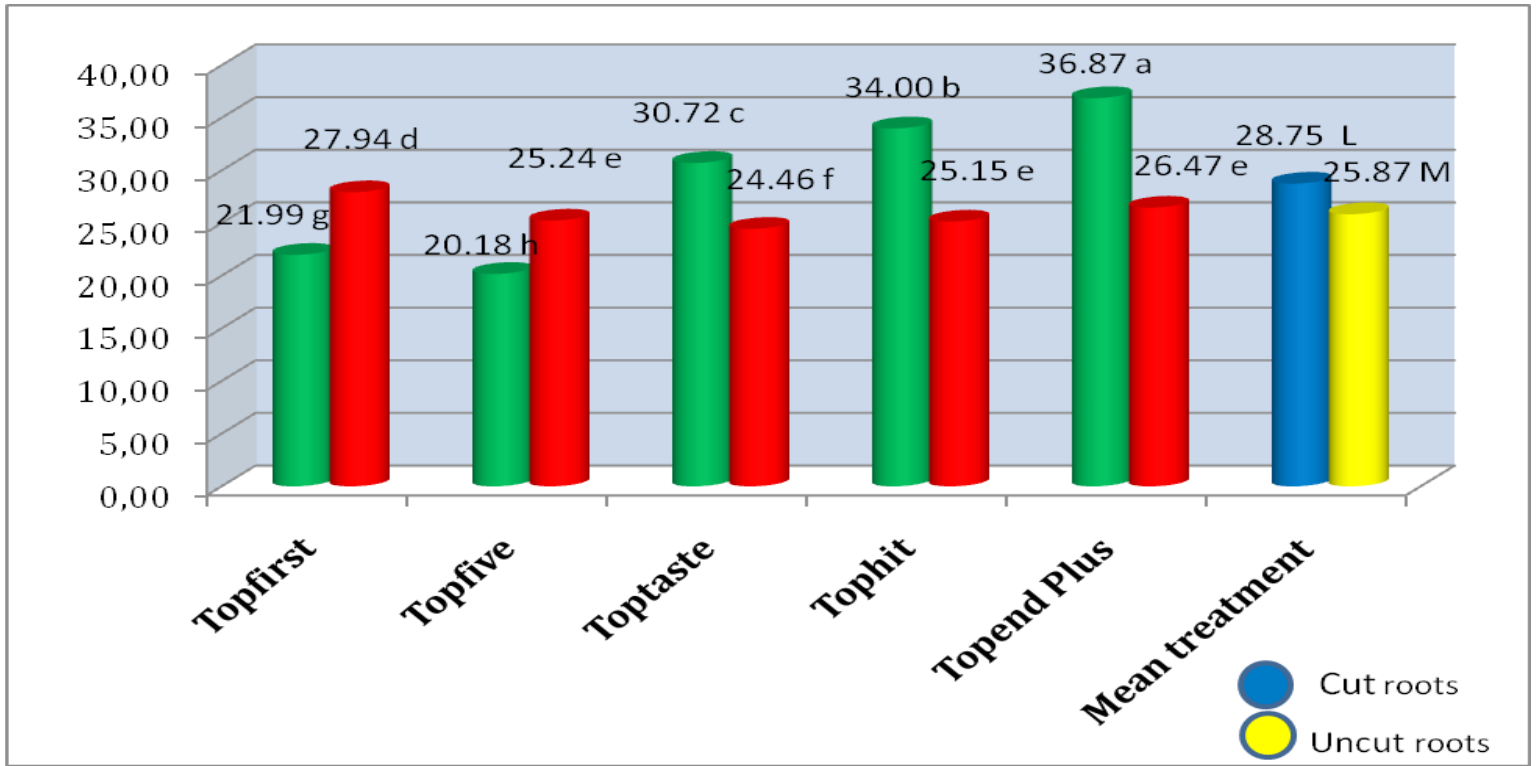

DS5\% cultivar $=1.64-1.78 ;$ DS5 $\%$ treatment $=1.04 ;$ DS5 $\%$ cultivar $\times$ treatment $=2.33-2.68$

Figure 1. The influence of root cutting and the cultivar on cumulative yield $(\mathrm{t} / \mathrm{ha})$

(Sînmihaiu Almasului, 2017 - 2018)

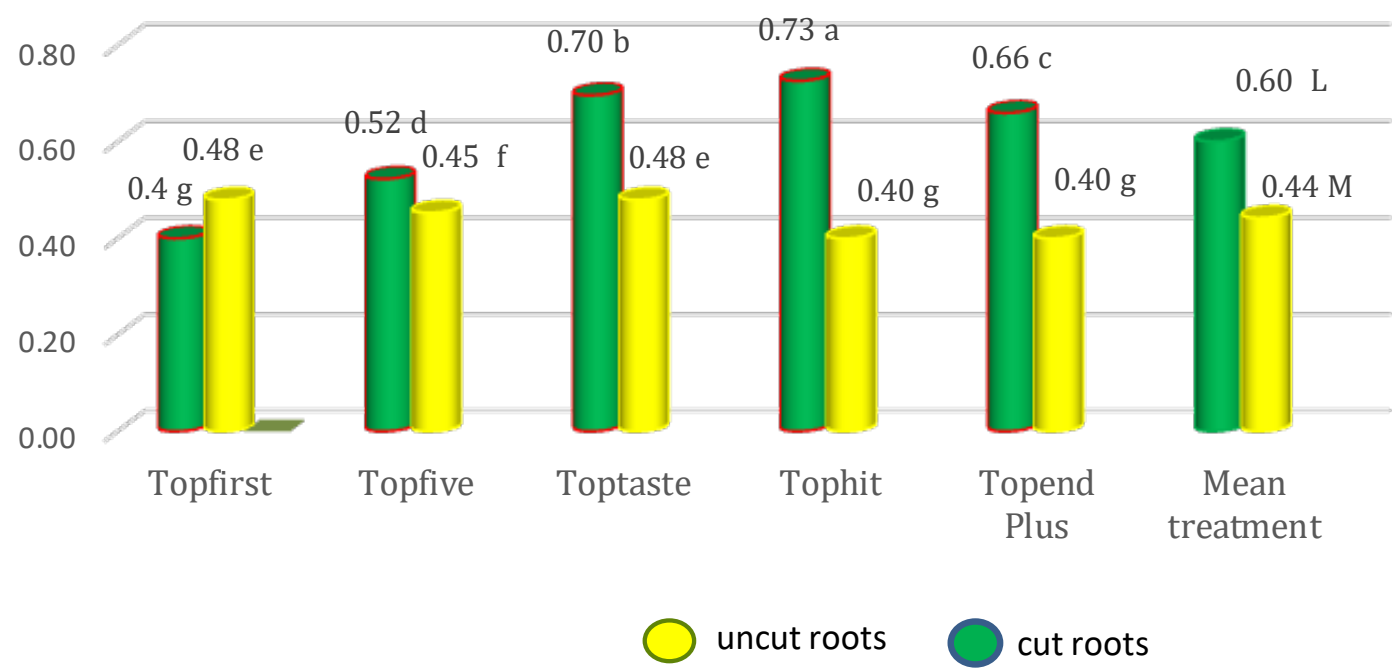

DS5 $\%$ cultivar $=0.06-0.07 ;$ DS5 $\%$ treatment $=0.3 ;$ DS5 $\%$ cultivar $\times$ treatment $=1.03-1.62$

Figure 2. The influence of root cutting and the cultivar on the productivity index of the plum trees $\left(\mathrm{kg} / \mathrm{cm}^{2}\right)$,

(Sînmihaiu Almasului, 2017 - 2018)

in variant of root pruning system $(28.75 \mathrm{t} / \mathrm{ha})$ followed by unpruned root system $(25.87 \mathrm{t} / \mathrm{ha})$ with differences statistically assured between these two treatments.

The best cumulative yield gave 'Topend Plus' (36.87 t/ha) and the lowest 'Topfive' (20.18 t/ ha). Regarding the combined influence of two experimental factors, the best cumulative yield was obtained at 'Topend Plus' (36.87 t/ha) followed by 'Tophit' (34.0 t/ha) in root pruned system.

In Denmark, root pruning has become a common practice for controlling canopy size in pear orchards (Wang et al., 2014).

Data of the Figure 2 show that root pruning increased productivity index in the experiment with the five plum cultivars. 
The lowest values of productivity index in unpruned system variant were obtained (0.6) and the biggest value in root pruned variant $(0.44)$. This means that cutting root is a safe measure that can increase productivity index and root pruning is an important measure in creating the right balance between growth and fruiting in high density plum orchards.

Yang et al. (2010), studied effects of root pruning on the vegetative growth and fruit quality of zhanhuadongzao trees. The yield of zhanhuadongzao was slightly enhanced by root pruning (12.97 kg in control; $13.86 \mathrm{~kg}$ at severe root cutting; 14.32 at moderate root cutting and $14.05 \mathrm{~kg}$ at light root cutting), but it did not reach statistically significant level. The contents of vitamin $C$ and total sugar in fruits were increased by root pruning. Only cypermethrin was detected and its concentration was lowest in severe root pruning treatment.

Early studies show that root pruning could reduce the yields of fruit trees due to lowered leaf area index hence a reduced photo-assimilate supply (Ferree 1989; Khan et al. 1998).

Yield efficiency (kg fruit per unit trunk crosssection area) and mean fruit weight were not affected by root pruning. However, root pruning in the dormant phase resulted in a greater proportion of the total crop being removed at the second harvest and a reduction in the proportion removed at the third harvest compared with control trees (Steven et al., 2011).

\section{Conclusions}

Cutting roots treatment had a strong influence on growth and fructification of studied plum cultivars within Top group, in high density culture system.

The trees length of annual branches, the trees height, the cross sectional aria of the trunk, the number of vegetative branches decrease if they proceeded to cut roots.

Cutting roots made a very good ratio between vegetative and fruiting branches of the trees and induced an optimum balance between growth and fruiting and reduced the number of vegetative branches.

The yield of the trees was higher in the variants with cutting roots treatment and the productivity index has been increased.

\section{Acknowledgements}

This research work is funded by the Ministry of Research and Innovation of Romania, Projects for Financing the Excellence in CDI, Contract no. 37PFE/06.11.2018

\section{References}

1. Asín L, Alegre S, Montserrat R (2007). Effect of paclobutrazol, prohexadione-Ca, deficit irrigation, summer pruning and root pruning on shoot growth, yield, and return bloom, in a 'Blanquilla' pear orchard. Scientia Horticulturae, 113: 142-148.

2. Cline JA, Embree CG, Hebb J, Nichols DS (2008). Performance of prohexadione-calcium on shoot growth and fruit quality of apple - effect of spray surfactants. Canadian Journal of Plant Science, 88: 165-174.

3. Elfving DC and Forshey CG (1976). Journal of the American Society fot Horticultural Science, 101: 290-293.

4. Ferree DC (1989). Growth and carbohydrate distribution of young apple trees in response to root pruning and tree density. HortScience, 24: 62-65.

5. Ferree DC (1992). Timing of root pruning influences vegetative growth, fruit size, biennial bearing, and yield of 'Jonathan' apple. Journal of the American Society for Horticultural Science, 172: 198-202.

6. Forshey CG, Elfving DC, Stebbins RL (1992). Training and pruning of apple and pear trees, American Society for Horticultural Science

7. Geisler D, Ferree DC (1984). The influence of root pruning and water relation, net photosynthesis, and growth of young Golden Delicious apple tree. Journal of the American Society for Horticultural Science, 109: 827-831.

8. Geisler D and Ferree DC (1984). Horticultural Reviews, 6: 155-188.

9. Hawerroth FJ, Petri JL, Fachinello JC, Herter FG, Prezorro ME, Hass LB, Pretto A (2012). Redução da poda hibernal e aumento da produção de pereiras 'Hosui' pelo uso de prohexadiona cálcio. Pesquisa Agropecuária Brasileira, 47:939-947.

10. Hugard J (1980). High density planting in French orchards: development and current achievement. Acta Hort. 114: 300-308.

11. Janssens P, Deckers T, Elsen F, Elsen A, Schoofs H, Verjans W, Vandendriessche H (2011). Sensitivity of root pruned 'Conference' pear to water deficit in a temperate climate. Agricultural Water Management, 99: 58-66.

12. Khan ZU, McNeil DL, Samad A (1998). Root pruning reduces the vegetative and reproductive growth of apple trees growing under an ultra high density planting system. Scientia Horticulturae, 77: 165-176.

13. Lang GA, Early JD, Martin GC and Darnell RL (1987). Endo, para and ecodormancy. Horticultural Science, 22: 371 -377 .

14. Maas F (2008). Strategies to control tree vigour and optimize fruit production in 'Conference' pears. Acta Horticulturae, 800: 139-146. 
15. Magda MN, Naglaa HS, Samia AA and Eman SA (2015). Effect of Some Horticultural Practices on Fruit Set, Yield and Quality of "Le-Conte" Pear Trees, Middle East Journal of Applied Sciences, 5: 1115-1127.

16. Mika A (1986). Horticultural Reviews, 8: 337-378.

17. Mitre V, Mitre I, Sestras AF, Sestras RE (2012). Effect of Root Pruning upon the Growth and Fruiting of Apple Trees in High Density Orchards, Bulletin USAMV Horticulture 69(1-2).

18. Pal MD, Mitre V (2016). Root pruning effect on growth and yield of Sweet cherry, Agricultura - Ştiinţă şi Practică no. 1-2 (97-98)/2016.

19. Pasa MS, Fachinello JC, Schmitz JD, de Souza ALK, Herter FG (2011) Hábito de frutificação e produção de pereiras sobre diferentes porta-enxertos. Pesquisa Agropecuária Brasileira, 4: 998-1005.

20. Schupp JR, Ferree DC (1990). Influence of time of root pruning on growth, net photosynthesis, and transpiration of young apple trees. Scientia Horticulturae, 42: 299-306.
21. Sharma S, Rehalia AS and Sharma SD (2009). Vegetative growth restriction in pome and stone fruits - a review. Agric. Rev. 30(1): 13-23.

22. McArtney SJ and Belton RP (2011). Apple shoot growth and cropping responses to root pruning, New Zealand Journal of Crop and Horticultural Science, 20(4): 383-390.

23. Vercammen J, Daele G, van Gomand A (2005). Root pruning: a valuable alternative to reduce the growth of 'Conference'. Acta Horticulturae, 671: 533-537.

24. Walker CD (1980). The development of intensive orchards in England: A historical note. Acta Horticulturae, 114: 309-317.

25. Wang Y, Travers S, Bertelsen MG, Thorup-Kristensen K, Petersen KK, Liu F (2014). Effect of root pruning and irrigation regimes on pear tree: growth, yield and yield components, Horticultural Science, 41(1): 34-43

26. Yang S, Xing S, Liu C, Du Z, Wang H and Xu Y (2010). Effects of root pruning on the vegetative growth and fruit quality of zhanhuadongzao trees, Horticultural Science, 37(1): 14-21. 